Complementi di Geometria Descrittiva-visibilita-ombre-chiaroscuro-prospettiva lineare. By Gino Loria. Milano, Ulrico Hoepli, 1924. $x i i+191$.

In his preface the author states that this will probably be the concluding volume of his series of books on descriptive geometry published by this firm. (The earlier books were (1) Metodi della Geometria Descrittiva, 1 st ed., 1909, 2 d ed., 1919; (2) Poliedri, Curve e Superfici, secondo $i$ Metodi della Geometria Descrittiva, 1912; (3) Storia della Geometria Descrittiva della Origini Sino ai Giorni Nostri. 'The two latter are reviewed in this BuLLETIN, vol. 20, p. 415, and vol. 28, p. 414.)

The eight chapters are grouped into three "books". The first, whose title is the same as the principal title of the volume, has chapters on visibility, on surfaces of the second order, and on ruled surfaces. Book II (shadows and chiaroscuro) has chapters entitled shadows cast by points, lines, and plane polygons; shadows on surfaces; ideas concerning chiaroscuro; and the illumination of surfaces. These two books are of the same length; but book III (linear perspective) is much briefer (18 pages) and attempts nothing beyond "definitions, constructions, and formulas".

In writing this brief introduction to the applications of descriptive geometry, the author had in mind the student with a good geometrical background rather than the draftsman who wants merely a set of "working rules" for making perspective drawings and putting in shades and shadows.

E. B. Cowley

Traité du Calcul des Probabilités et de ses Applications. By E. Borel, Tome III, Les Applications de la Théorie des Probabilités aux Sciences Economiques et Biologiques. Fascicule I. Assurances sur la Vie. Calcul des Primes, by Henri Galbrun. Paris, Gauthier-Villars, 1924. $311 \mathrm{pp}$.

This volume, the first part of a work on the mathematical side of life insurance, is just the sort of a book that we, here in America, would expect to be written by a professor of mathematics who was interested in life insurance. The best known writers in English on actuarial mathematics are actuaries who write for actuaries and who ever keep the practical applications in view. For them mathematics is simply a means to an end. The author is a French actuary and his book well illustrates the somewhat different view points of practical actuaries in this country and in France. Some allowance must, however, be taken for the fact that this volume is a part of a monumental work on the theory of probability and its applications.

Galbrun starts with the law of large numbers and proceeds in a straightforward way through the topics Bernoulli's theorem, Tchebycheff's theorem, interest, tables of mortality, Makeham's law, interpolation, 
summation, approximate integration, pure endowments, life annuities, premiums on various kinds of life insurance, joint life and survivorship problems, loading of premiums. This is all done in much the usual way, but more attention is paid to the elegance of the mathematical arguments and the calculus is used more freely than in many books on actuarial mathematics. A feature of the book is the discussion of the errors involved in the calculation of endowments, annuities, policy premiums, and so on. Along with average rates he computes a sort of safe rate which will cover all but one percent of the possible cases which may arise. In places, the methods used in the book will lead to much more arithmetic drudgery then is necessary, but on the whole it is a thoroughly readable and scholarly book on that part of actuarial mathematics which it covers.

\section{A. R. Crathorne}

Leitfaden zum Graphischen Rechnen. By Rudolf Mehmke. $2 \mathrm{~d}$ edition. Leipzig and Vienna, Franz Deuticke, 1924. viii $+183 \mathrm{pp}$.

Whether one does or does not believe in the practical value of graphic methods one must take seriously this guide to the subject. It is a mine of ingenious devices. Here are not only the usual graphic constructions for expressions of the form $\sum a b / c$ together with solutions of linear equations in two, three, four and more unknowns, with logarithmic scales for the more complicated functions, but exhaustive discussion of methods for integrating differential equations and the determination of moments of various sorts. In connection with logarithmic methods is a description of a "logarithmic compass" devised by Professor E. A. Brauer which has three points, the distance between two of which is a function of the distance between any other pair. Interesting use is made of this device.

As to the practical use of graphical methods one may be permitted to have serious doubts. Professor E. T. Whittaker, in his preface to his Calculus of Observations, remarks: "When the Edinburgh Laboratory was established in 1913 a trial was made, as far as possible, of every method which had been proposed for the solution of the problems under consideration, and many of these methods were graphic. During the ten years which have elapsed since then, the graphic methods have almost all been abandoned, as their inferiority has become evident, and at the present time the work of the Laboratory is almost exclusively arithmetic. A rough sketch on squared paper is often useful, but (except in descriptive geometry) graphic work performed carefully with instruments on a drawing-board is generally less rapid and less accurate than the arithmetic solution of the same problem." 